\title{
PENGEMBANGAN MODUL PEMBELAJARAN BERBASIS KETERAMIPILAN LITERASI
}

\author{
Sitti Fatimah S. Sirate \\ Sekolah Tinggi Ilmu Pendidikan dan Keguruan YPUP Makassar \\ fatimahsirate@yahoo.com \\ Risky Ramadhana \\ Sekolah Tinggi Ilmu Pendidikan dan Keguruan YPUP Makassar \\ rizkyramadhana53@gmail.com
}

\begin{abstract}
This study aims at developing a literacy-based instructional module on social arithmetic that can help the learning activities of grade VII students of Junior high school 1 of Gantarangkeke Bantaeng regency in order that they are more independent in reviewing, interpreting, interpreting, reasoning and communicating effectively and solving math problems in various contexts in everyday life. The type of this research is Research Development (Research and Development) by using modification of 4-D model combined with Romiszowski model. The model 4-D is taken only at the design level, especially on the aspect of choosing the teaching material development format, while the Romiszowski model includes three stages: (1) analysis, (2) synthesis and (3) evaluation, and all three stages are at the structural level of the second part of the Romiszowski model schema which emphasizes the development of printed materials in this case the product in the form of a learning module that meets the valid, practical and effective criteria. The results showed that the literacy-based math learning module meets the valid and practical criteria with a score of 3.73 including the highly valid category, and the 3.37 score belongs to the category of good in terms of practicality. This learning module also meets the effective criteria with the percentage completeness $79,19 \%$ which is in good category. Thus, the developed literacy-based math learning module has fulfilled the valid, practical and effective criteria. Keywords: model devepoment, media and technology, instruction
\end{abstract}

Keyword: Learning Module, Skill of Literacy

\section{PENDAHULUAN}

$\mathrm{P}$ endidikan merupakan kebutuhan manusia sampai kapan dan dimanapun ia berada. Pendidikan juga memiliki peranan yang sangat penting, sebab tanpa pendidikan manusia akan sulit berkembang. Dengan demikian pendidikan harus betul-betul diarahkan untuk menghasilkan manusia yang berkualitas dan mampu bersaing, serta memiliki budi pekerti dan moral yang baik. Peningkatan kualitas pembelajaran merupakan salah satu pilar upaya peningkatan mutu pendidikan secara keseluruhan. Upaya peningkatan mutu pendidikan adalah bagian terpadu dari upaya peningkatan kualitas manusia, baik aspek kemampuan, kepribadian, maupun tanggung jawab sebagai warga negara. 
Kualitas pendidikan sering dijadikan tolak ukur keberhasilan perkembangan suatu Negara. Pendidikanlah yang mampu memajukan dan mengembangkan kualitas SDM suatu Negara. Kualitas pendidikan Indonesia masih tergolong rendah, hal ini ditunjukkan oleh data hasil survei Trends in International Mathematics and Sciences Study (TIMSS) tahun 2011 Indonesia pada posisi ke-36 untuk bidang Matematika dari 40 negara yang disurvei dan mutu akademik antar bangsa melalui Programme for International Student Assessment (PISA) di bidang Matematika pada tahun 2012 menempatkan siswa Indonesia pada peringkat ke-64 dari 65 negara sampel. Hal ini berarti bahwa kemampuan siswa Indonesia dalam menyelesaikan soal-soal yang menuntut kemampuan untuk menelaah, memberi alasan, dan mengkomunikasikannya secara efektif, serta memecahkan dan menginterpretasikan permasalahan dalam berbagai situasi atau dengan kata lain bahwa keterampilan literasi masih sangat rendah.

Memperhatikan rendahnya kemampuan siswa Indonesia dalam survei tersebut, Pemerintah Indonesia, dalam hal ini Kementerian Pendidikan dan Kebudayaan sebenarnya telah mengantisipasinya dengan melakukan beberapa perubahan kurikulum. Salah satu perubahan kurikulum yang terbaru adalah kurikulum 2013 di mana pada kurikulum 2013 ini proses pembelajaran matematika dilaksanakan dengan pendekatan saintifik (Scientific Approach) atau dikenal pula dengan istilah pendekatan ilmiah (Kemdikbud, 2013). Berdasarkan Pedoman Umum Pembelajaran yang diatur dalam Permendikbud Nomor 81A Tahun 2013 tentang Implementasi Kurikulum 2013, dituliskan bahwa dalam pembelajaran melalui pendekatan ilmiah, dikenal melalui 5 tahapan/proses yakni: tahap mengamati (observing), menanya (questioning), mengumpulkan informasi yang bisa dilakukan melalui percobaanpercobaan (experimenting), mengasosiasi/menalar (associating), dan mengkomunikasikan (communicating).

Melalui pendekatan saintifik ini, siswa diajak dan dilatih untuk menalar, menganalisis, atau mengaitkan (associating) fenomena yang satu dengan fenomena yang lain. Kejadian pembelajaran matematika yang seperti ini dikenal dengan istilah literasi matematika. Sehingga pembelajaran matematika akan lebih bermakna apabila terdapat kesinambungan antara materi dengan aktivitas kehidupan sehari-hari di lingkungan tempat tinggal siswa yang digunakan sebagai sumber belajar.

Interaksi di kelas terjadi antara siswa, guru, dan bahan ajar. Guru bertugas membuat bahan ajar untuk digunakan oleh siswa untuk belajar mandiri. Keberhasilan dalam pembelajaran salah satunya dipengaruhi oleh penggunaan sumber belajar atau media yang digunakan selama proses pembelajaran. Dengan demikian perlu adanya bahan ajar dalam bentuk modul dalam proses pembelajaran. Modul adalah bahan ajar yang dirancang secara sistematis berdasarkan kurikulum dan dikemas dalam bentuk satuan pembelajaran terkecil dan memungkinkan dipelajari secara mandiri dalam satuan waktu tertentu agar siswa menguasai kompetensi yang diajarkan. Modul juga merupakan salah satu bahan ajar yang sesuai dengan karakteristik kurikulum 2013, 
yaitu dalam proses pembelajaran idealnya dapat melibatkan siswa secara aktif dan tidak hanya menekankan pada aspek kognitif namun juga pada aspek psikomotor dan sikap.

Salah satu SMP yang menjadi sekolah sasaran K13 di Kabupaten Bantaeng adalah SMP Negeri 1 Gantarangkeke. Berdasarkan observasi dan wawancara dengan guru matematika di sekolah tersebut menyatakan bahwa pembelajaran matematika di sekolah tersebut sudah menerapkan model pembelajaran cooperative dan model pembelajaran langsung namun belum menggunakan keterampilan literasi. Akibatnya tidak jarang terjadi pada saat pembelajaran siswa masih merasa bosan dan siswa belum mampu untuk merumuskan, menggunakan, dan menafsirkan matematika dalam berbagai konteks di kehidupan sehari-hari. Dan juga terungkap bahwa selama ini guru terkhususnya guru mata pelajaran matematatika belum pernah menggunakan bahan ajar modul. Bahan ajar yang digunakan hanya berupa buku dari pemerintah saja.

Oleh karena itu perlu dikembangkan bahan ajar yang mengacu pada keterampilan literasi dengan tujuan membantu siswa untuk memahami peran atau kegunaan matematika di dalam kehidupan sehari-hari sekaligus menggunakannya untuk membuat keputusan-keputusan yang tepat sebagai warga negara yang membangun, peduli, dan berpikir. Bahan ajar dalam hal ini berupa modul pembelajaran, yaitu paket belajar mandiri yang meliputi serangkaian pengalaman belajar yang direncanakan dan dirancang secara sistematis untuk membantu peserta didik mencapai tujuan belajar.

Literasi sering dihubungkan dengan huruf atau aksara. Literasi merupakan serapan dari kata dalam bahasa Inggris 'literacy', yang artinya kemampuan untuk membaca dan menulis. Menurut program Usaid Prioritas (2014) Literasi pada kelas awal hanya mengacu kemampuan berbahasa seseorang (menyimak, berbicara, membaca, dan menulis) untuk berkomunikasi dengan cara yang berbeda sesuai dengan tujuannya. Jadi literasi hanya dikaitkan pada kemampuan berkomunikasi secara tertulis saja.

Pada masa lalu dan juga masa sekarang, kemampuan membaca atau menulis merupakan kompetensi utama yang sangat dibutuhkan dalam melakukan kegiatan sehari-hari. Tanpa kemampuan membaca dan menulis, komunikasi antar manusia sulit berkembang ke taraf yang lebih tinggi. Gagasan umum dari literasi tersebut diserap dalam bidang-bidang yang lain. Salah satu bidang yang menyerapnya adalah bidang matematika, sehingga muncul istilah literasi matematika.

Literasi matematika secara umum diartikan sebagai suatu kesatuan dari pengetahuan, pemahaman, dan keterampilan yang dibutuhkan manusia untuk berfungsi secara efektif dalam kehidupan modern.

Definisi literasi matematika menurut draft assessment framework PISA 2012: Mathematical literacyis an individual's capacity to formulate, employ, and interpret mathematics in a variety of contexts. It includes reasoning mathematically and using mathematical concepts, procedures, facts, and tools to describe, explain, and predict phenomena. It assists individuals to recognise the role that mathematics plays in the 
world and to make the well-founded judgments and decisions needed by constructive, engaged and reflective citizens.

Berdasarkan definisi tersebut, literasi matematika diartikan sebagai kemampuan seseorang untuk merumuskan, menerapkan dan menafsirkan matematika dalam berbagai konteks, termasuk kemampuan melakukan penalaran secara matematis dan menggunakan konsep, prosedur, dan fakta untuk menggambarkan, menjelaskan atau memperkirakan fenomena/kejadian. Literasi matematika membantu seseorang untuk memahami peran atau kegunaan matematika di dalam kehidupan sehari-hari sekaligus menggunakannya untuk membuat keputusan-keputusan yang tepat sebagai warga negara yang membangun, peduli dan berpikir (Wardhani, 2011).

Modul adalah bahan ajar yang dirancang secara sistematis berdasarkan kurikulum tertentu dan dikemas dalam bentuk satuan pembelajaran terkecil dan memungkinkan dipelajari secara mandiri dalam satuan waktu tertentu agar siswa menguasai kompetensi yang diajarkan (Darmiyatun, 2013).

Modul pembelajaran menurut Winkel (2009), merupakan satuan program belajar mengajar yang terkecil, yang dipelajari oleh siswa sendiri secara perseorangan atau diajarkan oleh siswa kepada dirinya sendiri (self-instructional).

Modul adalah suatu cara pengorganisasian materi pelajaran yang memperhatikan fungsi pendidikan. Strategi pengorganisasian materi pembelajaran mengandung squencing yang mengacu pada pembuatan urutan penyajian materi pelajaran, dan synthesizing yang mengacu pada upaya untuk menunjukkan kepada pebelajar keterkaitan antara fakta, konsep, prosedur dan prinsip yang terkandung dalam materi pembelajaran (Indriyanti, 2010).

Menurut Santyasa (2008), secara prinsip tujuan pembelajaran adalah agar siswa berhasil menguasai bahan pelajaran sesuai dengan indikator yang telah ditetapkan. Hal ini disebabkan karena di dalam kelas berkumpul siswa dengan kemampuan yang berbeda-beda (kecerdasan, bakat, dan kecepatan belajar) maka perlu diadakan pengorganisasian materi, sehingga semua siswa dapat mencapai dan menguasai materi pelajaran sesuai dengan tujuan yang telah ditetapkan dalam waktu yang disediakan. Disamping pengorganisasian materi pembelajaran, juga perlu memperhatikan cara-cara mengajar yang disesuaikan dengan pribadi individu. Bentuk pelaksanaan cara mengajar tersebut adalah dengan membagi-bagi bahan pembelajaran menjadi unit-unit pembelajaran yang masing-masing bagian meliputi satu atau beberapa pokok bahasan. Bagian-bagian materi pembelajaran tersebut disebut modul.

Berdasarkan beberapa pengertian modul di atas maka dapat disimpulkan bahwa modul pembelajaran adalah salah satu bentuk bahan ajar yang dikemas secara sistematis dan menarik sehingga mudah untuk dipelajari secara mandiri.

Penggunaan modul sebagai fasilitas atau sumber belajar telah banyak diterapkan dan dikembangkan, dengan tujuan a) mempersingkat waktu yang diperlukan oleh siswa untuk menguasai tugas pelajaran tersebut; dan b)menyediakan waktu sebanyak yang 
diperlukan oleh siswa dalam batas-batas yang dimungkinkan untuk menyelenggarakan pendidikan yang teratur.

Modul pembelajaran merupakan salah satu bahan belajar yang dapat dimanfaatkan oleh siswa secara mandiri. Modul yang baik harus disusun secara sistematis, menarik, dan jelas. Modul dapat digunakan kapanpun dan dimanapun sesuai dengan kebutuhan siswa. Anwar (2010), menyatakan bahwa modul adalah bahan ajar yang disusun secara sistematis dan menarik yang mencakup isi materi, metode dan evaluasi yang dapat digunakan secara mandiri untuk mencapai kompetensi yang diharapkan dengan karakteristik modul pembelajaran sebagai berikut: 1) Self instructional, siswa mampu membelajarkan diri sendiri, tidak tergantung pada pihak lain; 2) Self contained, seluruh materi pembelajaran dari satu unit kompetensi yang dipelajari terdapat didalam satu modul utuh; 3) Stand alone, modul yang dikembangkan tidak tergantung pada media lain atau tidak harus digunakan bersama-sama dengan media lain; 4) Adaptif, modul hendaknya memiliki daya adaptif yang tinggi terhadap perkembangan ilmu dan teknologi; 5) User friendly, modul hendaknya juga memenuhi kaidah akrab bersahabat/akrab dengan pemakainya; 6) Konsistensi, konsisten dalam penggunaan font, spasi, dan tata letak.

Penelitian dan pengembangan atau research and development (R\&D) adalah suatu proses atau langkah-langkah untuk mengembangkan suatu produk baru atau menyempurnakan produk yang telah ada, yang dapat dipertanggungjawabkan (Syaodih, 2007). Produk tersebut tidak selalu berbentuk benda atau perangkat keras (hardware) seperti buku, modul, alat bantu pembelajaran dikelas atau di laboratorium, tetapi bisa juga perangkat lunak (software), seperti program komputer untuk pengolahan data, pembelajaran dikelas, perpustakaan atau laboratorium, ataupun model-model pendidikan, pembelajaran, pelatihan, bimbingan, evaluasi, manejemen, dan lainlain.

Menurut Sudjana (2005), bahwa dalam melaksanakan pengembangan perangkat pengajaran diperlukan modelmodel pengembangan yang sesuai dengan sistem pendidikan. Ada beberapa model pengembangan pembelajaran antara lain model Banathy, model Kemp, model Gerlach dan Ely, model PPSI, model Dick dan Carey, model 4-D, model dari Ilma, dan model dari Degeng. Yaumi (2015) menyatakan bahwa tidak ada satu model yang dapat digunakan untuk semua proses desain dan pengembangan. Semua model pasti memiliki kelebihan dan kelemahan. Itulah sebabnya seorang pengembang perlu mengadaptasi dan menggabungkan beberapa model sebagai landasan berpijak dalam menghasilkan produk.

Sejalan dengan pernyataan Yaumi di atas, Gustafson (2002) membagi model pengembangan itu kedalam tiga bahagian, yaitu (1) model yang berorientasi ruang kelas, (2) model yang berorientasi produk, dan (3) model yang berorientasi sistem.

Terdapat dua model yang dapat dipadukan dalam pengembangan bahan ajar, yaitu model Romiszowski dan Model 4 D. Dilihat dari segi strukturnya model Romiszowzki ini merupakan model penggabungan antara hirarki dan prosedural, Secara hirarki model 
ini terdiri atas 3 fase (1) analisis, (2) sintesis dan (3) evaluasi. Secara prosedural model ini terdiri atas 5 bahagian (1) dasar teori, (2) bahan ajar cetak, (3) bahan ajar berbasis komputer, (4) teknik pengembangan bahan audio visual, (5) evaluasi bahan ajar,

Model pengembangan menurut Thiagarajan (1974) terdiri atas empat tahap, sehingga disebut FOUR-D (Model 4-D). Keempat tahap itu adalah pendefinisian (define), perancangan (design), pengembangan (develop) dan penyebaran (dessiminate).

Berdasarkan latar belakang masalah yang telah dibahas, maka rumusan masalah dalam penelitian ini adalah "Bagaimana modul pembelajaran matematika berbasis keterampilan literasi yang valid, praktis dan efektif?"

Adapun tujuan yang ingin dicapai dari penenelitian ini adalah untuk mengetahui deskripsi tingkat kevalidan, kepraktisan dan keefektifan modul pembelajaran matematika berbasis keterampilan literasi.

Manfaat yang diharapkan dapat diperoleh dari hasil penelitian ini mencakup manfaat bagi kepala sekolah, guru dan tenaga pengajar, peserta didik, dan bagi peneliti. Bagi kepala sekolah, hasil penelitian ini dapat dijadikan sebagai dasar pola pembinaan peningkatan profesionalisme guru. Bagi guru dan tenaga pengajar lainnya hasil penelitian ini dapat dijadikan sebagai bahan informasi guru tentang pengembangan modul pembelajaran matematika berbasis keterampilan literasi dan dapat dijadikan sumber wawasan bagi guru ingin melakukan inovasi pembelajaran, khususnya pembelajaran matematika. Bagi peserta didik, penelitian ini dapat mengembangkan keterampilan literasi matematikanya dan juga dapat lebih terlatih untuk belajar mandiri dengan menggunakan modul pembelajaran. Bagi peneliti, hasil penelitian ini dapat dijadikan sebagai bahan informasi untuk mengembangkan penelitian selanjutnya terutama yang terkait dengan penelitian ini.

\section{METODOLOGI}

Penelitian ini adalah penelitian pengembangan (Research and Development) yang mengembangkan bahan ajar berupa modul pembelajaran matematika berbasis keterampilan literasi dengan mengadaptasi model pengembangan dari Romiszowski dan 4-D. Model Romiszowski mencakup desain, sintesis dan evaluasi yang didukung dengan Thiagarajan yang dikenal dengan 4-D yaitu define (pendefenisian), design (perancangan), develop (pengembangan) dan disseminate (penyebaran).

Penelitian ini dilaksanakan SMP Negeri 1 Gantarangkeke dengan subjek penelitiannya adalah siswa kelas VII tahun ajaran 2016/2017. Penelitian ini telah dilaksanakan pada tahun ajaran 2016/2017 dengan empat tahap yaitu tahap pendefenisian, tahap perancangan, tahap pengembangan, dan tahap penyebaran.

\section{A. Tahap Pendefinisian/Analisis}

Tahap ini dilakukan untuk menganalisis dan mendesinisikan syarat-syarat pembelajaran yang meliputi tujuan pembelajaran dan pembatasan materi pembelajaran. Adapun langkah-langkahnya sebagai berikut: 


\section{Analisis Awal-Akhir}

Kegiatan analisis awal-akhir dilakukan untuk menetapkan masalah dasar yang diperlukan dalam modul pembelajaran dengan mempertimbangkan kurikulum yang berlaku. SMP Negeri 1 Gantarangkeke merupakan SMP Negeri yang menjadi sasaran K13. Pembelajaran dengan implementasi Kurikulum 2013 dilaksanakan dengan pendekatan saintifik dengan 5 tahapan/proses yakni: tahap mengamati, menanya, mengumpulkan informasi, mengasosiasi/menalar, dan mengkomunikasikan. Sehingga diperlukan bahan ajar yang menunjang pelaksanaan kurikulum yang berlaku, yaitu kurikulum 2013.

\section{Analisis Siswa}

Analisis siswa merupakan telaah tentang karakteristik siswa kelas VII SMP Negeri 1 Gantarangkeke. Tujuan dari analisis ini adalah untuk menelaah karakteristik siswa yang meliputi latar belakang pengetahuan siswa, bahasa yang digunakan dan perkembangan kognitif siswa. Hasil telaah tersebut digunakan sebagai bahan pertimbangan untuk mengembangkan modul pembelajaran matematika berbasis keterampilan literasi pada materi aritmatika sosial.

\section{Analisis Konsep}

Analisis konsep bertujuan untuk mengidentifikasi, merinci, dan menyusun secara sistematis konsep-konsep utama yang akan dipelajari siswa. Konsep-konsep itu disusun secara hirarkis dan memilahmilah konsep itu berdasarkan peranannya dalam materi yang harus diajarkan. Materi yang akan dibahas dalam penelitian ini adalah materi aritmatika sosial di SMP kelas VII dengan mengacu pada

Kurikulum 2013.

\section{Analisis Tugas}

Analisis tugas ini dilakukan setelah mengetahui konsep yang akan diajarkan sehingga dapat diketahui tugas-tugas yang harus diselesaikan siswa selama pembelajaran dilaksanakan. Dan dapat memudahkan guru untuk merumuskan tujuantujuan khusus (indikator pencapaian hasil belajar) yang akan dicapai.

\section{B. Tahap Perancangan/Sintesis}

Pada tahap ini dilakukan perancangan atau strategi memproduksi bahan ajar berupa draft modul pembelajaran matematika. c) Tahap Evaluasi

Tahap evaluasi merupakan tahap penilaian terhadap pengembangan modul pembelajaran matematika untuk penilaian kevalidan modul dilihat dari aspek kelayakan isi, aspek penyajian, aspek bahasa, dan aspek evaluasi modul untuk mengetahui kualitas bahan ajar yang dikembangkan. Selain itu, pada tahap ini dilakukan pula penilaian terhadap kepraktisan dengan melihat keterlaksanaan pembelajaran serta respon siswa dan respon guru, dan keefektifan modul pembelajaran matematika berbasis keterampilan literasi yang dinilai dengan tes hasil belajar setelah pembelajaran dengan modul dilakukan. 
Data yang telah dikumpulkan dengan menggunakan instrumen selanjutnya dianalisis secara kuantitatif untuk mengetahui kualitas modul yang dihasilkan.

1. Analisis Data Kevalidan

Data hasil validasi para ahli untuk format modul pembelajaran dianalisis dengan mempertimbangkan penilaian, masukan, komentar, dan saran-saran dari validator. Hasil analisis tersebut dijadikan sebagai pedoman untuk merevisi format modul pembelajaran sesuai dengan butirbutir penilaian yang masih mendapat penilaian kurang, sebelum dilakukan uji coba.

2. Analisis Keterlaksanaan Pembelajaran

Data tentang keterlaksanaan pembelajaran diperoleh dari lembar observasi

keterlaksanaan pembelajaran. Penghitungan untuk mendapatkan persentase

keterlaksanaan pembelajaran untuk semua

pertemuan dilakukan dengan rumus sebagai berikut.

$$
\bar{k}=\underset{\text { banyakpengamatan } n}{ }{ }^{1} \times{ }^{\sum k} \times 100 \%
$$

Keterangan:

$\bar{k}=$ persentase skor rata-rata $\mathrm{k}=$ jumlah nilai yang diperoleh

$n$ = banyaknya butir

3. Analisis Data Respon Siswa dan Guru

Data respon siswa diperoleh dari angket respon siswa terhadap penggunaan modul dalam kegiatan pembelajaran, dan selanjutnya dianalisis dengan analisis persentase. Secara rinci analisis data ini dilakukan dengan langkah-langkah: a) Menghitung banyak siswa yang memberi respon positif sesuai dengan aspek yang ditanyakan; b) Menghitung persentase pada langkah (a); c) Menentukan kategori untuk respon positif siswa dengan cara mencocokkan hasil persentase dengan kriteria yang ditetapkan.

Modul pembelajaran matematika berbasis keterampilan literasi yang dikembangkan akan memenuhi kriteria kepraktisan jika lebih dari 50\% siswa memberikan respon positif terhadap minimal $70 \%$ jumlah aspek yang ditanyakan.

4. Analisis Data Tes Hasil Belajar

Hasil belajar siswa secara individu diperoelh dari hasil posttest literasi yaitu hasil penskoran padajawaban siswa. Ketentuan pemberian skor pada jawaban siswa setiap butirsoal aturan pemberian skor posttest literasi Matematika.

\section{HASIL PENELITIAN DAN PEMBAHASAN}

Berdasarkan tujuan penelitian dengan mengacu pada metodologi, maka telah dilakukan penelitian pengembangan modul pembelajaran matematika berbasis keterampilan literasi. Penelitian pengembangan ini merujuk pada tiga syarat kualitas yaitu valid, praktis dan efektif serta disusun dan dikembangkan dengan mengadaptasi model pengembangan dari Romiszowski dan 4-D. Model Romiszowski mencakup 
desain, sintesis dan evaluasi yang didukung dengan Thiagarajan yang dikenal dengan 4D yaitu define (pendefenisian), design (perancangan), develop (pengembangan) dan disseminate (penyebaran). Berikut ini dideskripsikan hasil penelitian beserta hasil analisis data yang telah diperoleh.

\section{A. Tahap Analisis}

Hal-hal yang dianalisis meliputi kebutuhan siswa kelas VII dan kurikulum yang bersesuaian dengan materi Aritmetika Sosial. Proses yang dilakukan pada tahap analisis dijelaskan sebagai berikut.

Analisis Awal-Akhir

Pada tahap ini ditemukan masalah dasar yaitu masih kurangnya bahan ajar yang digunakan oleh guru serta sumber belajar untuk para peserta didik yang sesuai dengan kurikulum yang berlaku di SMP Negeri 1 Gantarangkeke. SMP Negeri 1 Gantarangkeke merupakan SMP Negeri yang menjadi sasaran K13. Pembelajaran dengan implementasi Kurikulum 2013 dilaksanakan dengan pendekatan saintifik dengan 5 tahapan/proses yakni: tahap mengamati, menanya, mengumpulkan informasi, mengasosiasi/menalar, dan mengkomunikasikan. Sehingga diperlukan bahan ajar yang menunjang pelaksanaan kurikulum yang berlaku, yaitu kurikulum 2013.

\section{Analisis Siswa}

Analisis siswa merupakan telaah tentang karakteristik siswa kelas VII SMP Negeri 1 Gantarangkeke. Tujuan dari analisis ini adalah untuk menelaah karakteristik siswa yang meliputi latar belakang pengetahuan siswa, bahasa yang digunakan.Siswa kelas $\mathrm{VII}_{\mathrm{A}}$ telah memperoleh materi operasi bilangan bulat, bilangan pecahan, bentuk aljabar dan persamaan linier satu variabel sebagai materi prasyarat dalam proses belajar menggunakan modul ini, serta bahasa yang digunakan para siswa pada saat kegiatan belajar mengajar adalah bahasa Indonesia.

\section{Analisis Konsep}

Analisis konsep bertujuan untuk mengidentifikasi, merinci, dan menyusun secara sistematis konsep-konsep utama yang akan dipelajari siswa. Konsep-konsep itu disusun secara hirarkis dan memilah-milah konsep itu berdasarkan peranannya dalam materi yang harus diajarkan. Dalam hal ini, konsep materi yang akan diajarkan dengan menggunakan modul pembelajaran matematika berbasis keterampilan literasi yaitu pokok bahasan aritmatika sosial. Hasil dari analisis konsep diperoleh indikator yang akan dibahas pada modul tersebut sebagai berikut:

1. Menentukan keuntungan dan kerugian dalam transaksi jual beli barangdengan menggunakan rumus.

2. Menentukan persentase untung dan rugi serta menggunakannya dalam memecahkan masalah sehari-hari.

3. Menggunakan rumus bunga tunggal untuk memecahkan masalah yang berkaitan dengan kegiatan ekonomi sehari-hari. 
4. Menentukan besarnya diskon dan pajak.

5. Menentukan bruto, tara dan netto

\section{Analisis Tugas}

Analisis tugas dilakukan untuk menentukan isi materi dan tugas-tugas agar peserta didik mampu memahami materi pokok aritmatika sosial. Kegiatan yang dilakukan adalah menentukan tugas-tugas peserta didik sebagai pengalaman belajar yang sesuai dengan materi pokok, sehingga indikator hasil belajar dapat tercapai. Analisis tugas meliputi :

- Analisis Struktur Isi

Analisis struktur isi bertujuan untuk menyajikan materi secara garis besar yang sesuai dengan kurikulum yang berlaku pada SMP Negeri 1 Gantarangkeke.

- Analisis Prosedural

Analisis ini dilakukan untuk mengidentifikasi tahap-tahap penyelesaian tugas yang harus dilakukan oleh peserta didik sesuai dengan materi yang terkandung dalam modul. Diharapkan dari analisis ini, peserta didik dapat.memahami materi yang disajikan dalam mediapembelajaran berupa modul pembelajaran.

\section{Spesifikasi Tujuan Pembelajaran}

Dari analisis konsep dan analisis tugas yang telah dilakukan, dihasilkan tujuan pembelajaran khusus yang merupakan dasar untuk menyusun tes dan merancang modul pembelajaran matematika. Tujuan pembelajarannya yaitu: siswa dapat menentukan keuntungan dan kerugian dalam transaksi jual beli barangdengan menggunakan rumus, siswa dapat menentukan persentase untung dan rugi serta menggunakannya dalam memecahkan masalah sehari-hari, siswa dapat menggunakan rumus bunga tunggal untuk memecahkan masalah yang berkaitan dengan kegiatan ekonomi sehari-hari, siswa dapat menentukan besarnya diskon dan pajak, serta siswa dapat menentukan bruto, tara dan netto.

\section{B. Tahap Perencanaan/Sintesis}

Pada tahap ini, peneliti merancang strategi memproduksi modul pembelajaran matematika berbasis keterampilan literasi yang menjadi draf I dan di validasi oleh tim validator. Hal-hal yang dilakukan adalah sebagai berikut:

1. Menentukan spesifikasi produk modul sebagai sumber belajar

Spesifikasi produk modul yang dikembangkan yaitu berupa modul cetak ukuran kertas A4 yang didalamnya terdiri dari Kompetensi Inti (KI), Kompetensi dasar (KD), Indikator, Materi yang dikembangkan dengan menyajikan contoh-contoh tentang aritmatika sosial yang berbasis pada keterampilan literasi peserta didik. Selanjutnya uji kompetensi untuk mengetahui kemampuan siswa pada materi yang disajikan pada modul tersebut. 
2. Membuat dan merancang modul yang akan dikembangkan

Modul pembelajran matematika berbasi keterampilan literasi yang dikembangkan terdiri dari 5 kegiatan belajar yang terdiri dari: Kegiatan Belajar 1 adalah Menentukan besar keuntungan dan kerugian, Kegiatan Belajar 2 adalah Menentukan persentase keuntungan dan kerugian, Kegiatan Belajar 3 Menentukan besar bunga tunggal, Kegiatan Belajar 4 adalah Menentukan diskon dan pajak, dan Kegiatan Belajar 5 adalah Menenentukan netto, bruto, dan tara.

\section{Membuat struktur isi}

Membuat struktur isi mengikuti prinsip-prinsip mengidentifikasi kompetensi Inti, kompetensi dasar, merumuskan indikator pembelajaran, menyusun strategi pembelajaran, mengembangkan materi pembelajaran dan merancang instrumen evaluasi. Pengembangan dilakukan dengan berpedoman kepada kurikulum yang digunakan di sekolah.

\section{Tahap Evaluasi}

Tahap evaluasi merupakan tahap penilaian terhadap pengembangan modul pembelajaran matematika untuk penilaian kevalidan modul dilihat dari aspek kelayakan isi, aspek penyajian, aspek bahasa, dan aspek evaluasi modul untuk mengetahui kualitas bahan ajar yang dikembangkan. Selain itu, pada tahap ini dilakukan pula penilaian terhadap kepraktisan dengan melihat keterlaksanaan pembelajaran serta respon siswa dan respon guru, dan keefektifan modul pembelajaran matematika berbasis keterampilan literasi yang dinilai dengan tes hasil belajar setelah pembelajaran dengan modul dilakukan. Tahap ini meliputi beberapa kegiatan berikut.

1. Validasi Ahli

Pada tahap ini dilakukan validasi modul yang telah dibuat yaitu draf 1, yang meliputi validasi materi. Modul pembelajaran matematika berbasis keterampilan literasi ini divalidasi oleh para ahli berupa pemberian nilai pada setiap item kriteria validitas, disertai catatan-catatan atau saran- saran pada bagian yang perlu diperbaiki. Aspekaspek yang diperhatikan dalam memvalidasi modul pembelajaran matematika berbasis keterampilan literasi yang dihasilkan ini adalah aspek kelayakan isi, aspek kelayakan penyajian, aspek kelayakan bahasa dan aspek evaluasi modul. Dengan kategori validitas yaitu:

$$
\begin{aligned}
3,5 \leq M \leq 4,0 & \text { sangat valid } \\
2,5 \leq M<3,5 & \text { valid } \\
1,5 \leq M<2,5 & \text { cukup valid } \\
M \leq 1,5 & \text { tidak valid }
\end{aligned}
$$

Keterangan:

$\mathrm{M}=\bar{A}_{\iota}$ untuk mencari validitas setiap aspek

$\mathrm{M}=\bar{X}$ untuk mencari validitas keseluruhan aspek 
Dari hasil analisis validasi ahli terhadap modul pembelajaran matematika berbasis keterampilan literasi diperoleh rangkuman sebagai berikut:

Tabel 5.1. Ringkasan hasil validasi ahli modul pembelajaran matematika berbasis keterampilan literasi

\begin{tabular}{|c|c|c|c|}
\hline o. & Aspek penilaian & $\overline{A_{\imath}}$ & Keterangan \\
\hline & kelayakan isi & 3,45 & Valid \\
\hline & kelayakan penyajian & 3,85 & Sangat valid \\
\hline . & kelayakan bahasa & 3,60 & Sangat valid \\
\hline & evaluasi modul & 4,00 & Sangat valid \\
\hline & Rata-rata penialain $(\bar{X})$ & 3,73 & Sangat valid \\
\hline
\end{tabular}

Hasil analisis sebagaimana pada tabel di atas, menunjukkan bahwa berdasarkan kriteria validitas yaitu $3,5 \leq \mathrm{M} \leq 4,0$ (dengan $\mathrm{M}=\bar{X}$ untuk mencari validitas keseluruhan aspek), maka ditinjau dari keseluruhan aspek, modul pembelajaran matematika berbasis keterampilan literasi dinyatakan memenuhi syarat validitas.Hal ini berarti bahwa modul yang dikembangkan memenuhu kriteria modul yang valid. Selanjutnya saran-saran dari para validator digunakan sebagai bahan pertimbangan dan landasan untuk melakukan revisi. Setelah draft 1 dilakukan perbaikan (revisi 1) maka diperoleh modul pembelajaran matematika draft 2.

\section{Ujicoba Terbatas}

Pada tahap uji coba terbatas ini, draf 2 yang telah direvisi berdasarkan saran dan hasil validasidilakukan hanya satu kali terbatas pada satu kelas. Tujuan ujicoba ini adalah untuk mendapatkan saran dari siswa dan guru di lapangan dalam rangka untuk merevisi modul pembelajaran matematika draft 2. Kegiatan pembelajaran pada langkah ujicoba ini dilakukan oleh guru kelas.Rangkaian kegiatan ujicoba ada dua tahap, yaitu pelaksanaan proses pembelajaran dan tes akhir setelah ujicoba selesai.Setelah selesai mempelajari modul mereka diberikan angket untuk menilai kepraktisan dari modul, selain itu mereka juga diminta untuk

menuliskan komentar mereka terhadap keterpakaian modul. Keseluruhan hasil uji coba dianalisis dan hasilnya menjadi dasar perbaikan modul pembelajaran untuk draft akhir.

1. Analisis data kepraktisan modul pembelajaran

Indikator yang digunakan untuk menentukan kepraktisan modul pembelajaran yaitu; (1) keterlaksanaan pembelajaran, (2) respon siswa dan guru. Hasil analisis data 
kepraktisan modul pembelajaran setelah ujicoba dilaksanakan adalah:

a. Keterlaksanaan pembelajaran

Hasil analisis keterlaksanaan pembelajaran dengan menggunakan modul pembelajaran berbasis literasi diperoleh persentase keterlaksanaan sebesar $94 \%$ berdasarkan kriteria keterlaksanaan berada pada kategori sangat baik. Jika dilihat dari analisis kepraktisan modul pembelajaran di atas, dimana modul pembelajaran yang dihasilkan dikatakan memenuhi kualifikasi praktis jika persentase rata-rata keterlaksanaan kegiatan pembelajaran memenuhi kriteria minimal baik, dapat disimpulkan bahwa modul pembelajaran matematika berbasis keterampilan literasi memenuhi kriteria praktis.

b. Respon siswa dan respon guru

Dari hasil analisis respon siswa terhadap modul pembelajaran matematika berbasis keterampilan literasi diperoleh rangkuman sebagai berikut:

Tabel 5.2. Ringkasan hasil respon siswa terhadap modul pembelajaran matematika berbasis keterampilan literasi

\begin{tabular}{llll}
\hline & Aspek penilaian & $\boldsymbol{X}_{\boldsymbol{i}}$ & Keterangan \\
o. & Ketertarikan & 3,33 & Baik \\
\hline & Materi & 3,32 & Baik \\
. & & \\
& Bahasa & 3,47 & Sangat Baik \\
\hline & & & \\
\hline
\end{tabular}

Dari tabel ringkasan respon yang diberikan pada siswa terhadap uji coba menentukan kepraktisan dari modul diperoleh rata-rata respon siswa sebesar 3,37 yang dikategorikan baik, dengan persentase siswa yang memberi respon positif secara keseluruhan yaitu 99\%, dengan rincian untuk aspek ketertarikan persentase siswa yang member respon positif sebesar 98\%, aspek materi sebesar 99\% dan aspek bahasa sebesar $100 \%$.

Berdasarkan kriteria kepraktisan yang ditinjau dari respon siswa yaitu produk yang dikembangkan dikatakan memiliki derajat kepraktisan yang baik, jika minimal kriteria kepraktisan yang dicapai adalah kriteria baik, maka berdasarkan tabel 5.2 di atas dapat dikatakan bahwa modul pembelajaran matematika berbasis keterampilan literasi memiliki derajat kepraktisan yang baik atau dengan kata lain bahwa modul yang dikembangkan memenuhi kriteria praktis.

Selain itu, dari hasil analisis data respon guru dapat dilihat dari tabel berikut: 
Tabel 5.3. Ringkasan hasil respon guru terhadap modul pembelajaran matematika berbasis keterampilan literasi

\begin{tabular}{lcl}
\hline Respon Guru & $\boldsymbol{X}_{\boldsymbol{i}}$ & Keterangan \\
\hline G1 & 3,45 & Sangat Baik \\
G2 & 3,40 & Baik \\
\hline Rata-rata respon guru $(\overline{\boldsymbol{X}})$ & 3,43 & Sangat Baik \\
\hline
\end{tabular}

Dari tabel 5.3 di atas diperoleh rata-rata respon guru mata pelajaran matematika di SMP Negeri 1 Gantarangkeke sebesar 3,43. Jika disesuaikan dengan pengkategorian respon guru termasuk pada kategori sangat baik dan menyatakan bahwa modul yang dikembangkan dapat mempermudah proses penyampaian materi serta pembelajaran.

Berdasarkan analisis kepraktisan modul pembelajaran di atas, modul pembelajaran yang dihasilkan dikatakan memenuhi kualifikasi praktis jika skor rata-rata angket respon siswa dan guru memenuhi kriteria minimal baik dan persentase rata-rata keterlaksanaan kegiatan pembelajaran memenuhi kriteria minimal baik. Sehingga, dengan memperhatikan keterlaksanaan pembelajaran dan respon siswa serta respon guru, dapat disimpulkan bahwa modul pembelajaran yang dikembangkan memenuhi kriteria praktis.

2. Analisis data keefektifan modul pembelajaran

Keefektifan modul ini dapat diketahui dari hasil posttest siswa. Hasil posttest siswa dapat dilihat pada tabel berikut.

Tabel 5.4 Ketuntasan belajar siswa

\begin{tabular}{lclc}
\hline Kategori & Banyak Siswa & Keterangan & \% ketuntasan \\
\hline Level 1 & 1 & Tidak tuntas & $79,19 \%$ \\
Level 2 & 4 & Tidak tuntas & \\
Level 3 & 13 & Tuntas & \\
Level 4 & 3 & Tuntas & \\
Level 5 & - & - & \\
Level 6 & - & & - \\
\hline Jumlah & 21 & &
\end{tabular}

Dari hasil posttest literasi matematika yang dirangkum pada tabel 5.3 diketahui bahwa sebanyak 16 dari 21 siswa telah mencapai kemampuan literasi matematikadengan persentase ketuntasan mencapai $76,19 \%$ yaitu pada kategori baik.

Sebanyak 3 orang siswa mampu mencapai level 4. Terdapat 13 orang siswa mencapai level 3, 4 orang siswa hanya mampu mencapai level 2, dan satu orang berada pada level 1. Rata-rata nilai kelas adalah 507 menunjukkan bahwa rata-rata kemampuan literasi matematika siswa berada pada level 3. Dari hasil posttest literasi matematika dapat disimpulkan bahwa modul yang dikembangkan efektif digunakan. 


\section{Pembahasan}

\section{Kevalidan Modul Pembelajaran Matematika}

Berdasarkan penilaian ahli dan pakar terhadap modul diperoleh nilai rata-rata keseluruhan 3,75 dengan kategori "sangat valid", ini menunjukkan bahwa modul pembelajaran matematika berbasis keterampilan literasi yang dikembangkan memenuhi kriteria kevalidan. Meskipun begitu terdapat beberapa saran perbaikan dari para ahli untuk dilakukan revisi agar modul pembelajaran yang dikembangkan mejadi lebih baik.Modul pembelajaran matematika bebasis kereampilan literasi yang dikembangkan dapat dikatakan valid jika semua ahli yang memvalidasi menyatakan valid. Pendapat ini didukung oleh hasil penelitian Sawitri(2014) yang menyatakan bahwa modul pembelajaran yang berkualitas dan layak digunakan jika telah memenuhi standar kevalidan yang dinilai oleh ahli dan pakar.

\section{Kepraktisan Modul Pembelajaran Matematika}

a. Keterlaksanaan pembelajaran

Berdasarkan kriteria keterlaksanaan pembelajaran menggunakan modul berbasis keterampilan literasi persentase keterlaksanaan sebesar 94\% yang berarti keterlaksanaan pembelajaran menggunakan modul pembelajaran berbasis keterampilan literasi terlaksana dengan sangat baik dan siswa terlibat aktif dalam pembelajaran.Selain itu, tampak bahwa modul yang dikembangkan mampu mengarahkan siswa untuk terlibat aktif dalam kegiatan pembelajaran dan berinteraksi dengan teman serta guru untuk menyampaikan dan memecahkan permasalahan atau pertanyaan yang berkaitan dengan isi materi modul pembelajaran. Jadi jika ditinjau dari aspek keterlaksanaan modul pembelajaran yang dikembangkan telah memenuhi syarat kepraktisan. Hal ini sejalan dengan hasil penelitian yang dilakukan oleh Ismail (2013) yang menyatakan bahwa keterlaksanaan pembelajaran yang baik adalah jika derajat keterlaksanaan pembelajaran yang dicapai tersebut minimal berkategori tinggi atau baik.

b. Respon siswa dan respon guru

Respon siswa terhadap kegiatan pembelajaran menggunakan modul pembelajaran menunjukkan kategori respon positif, dimana dari tiga aspek yang dinilai rata-rata siswa memberikan respon yang positif yaitu untuk aspek ketertarikan persentase respon positif yang diberikan siswa sebesar 98\%, untuk aspek materi persentase respon positif siswa sebesar $99 \%$ dan untuk bahasa $100 \%$ siswa memberukan respon yang positif. Kemudian jika dilihat dari hasil rata-rata skor respon siswa untuk menentukan kepraktisan dari modul sebesar 3,38 yang dikategorikan sangat baik. Selain itu, respon guru berada pada kategori sangat baik dengan rata-rata respon guru yaitu sebesar 3,43.

Respon positif siswa terhadap modul pembelajaran disebabkan karena siswa dilibatkan secara langsung dalam proses pembelajaran, dimana dalam proses pembelajaran siswa mengembangkan sendiri pengetahuannya melalui kegiatan literasi serta kegiatan mengamati, menanya, ngumpulkan informasi, mengasosiasi, dan mengkomunikasikan yang sesuai dengan kurikulum 2013, sedangkan selama ini siswa 
cenderung pasif dan hanya menunggu informasi serta jawaban dari temannya yang mereka anggap mampu dalam hal pengetahuan dan juga siswa sekedar menerima informasi dari guru sehingga siswa kaya akan teori tetapi lemah dalam pengaplikasiannya. Selain itu pada modul terdapat petunjuk penggunaan modul pembelajaran sehingga mereka mampu melakukan pembelajaran secara mandiri, dan juga didukung oleh bahasa dan petunjuk yang mampu menuntun mereka untuk melakukan kegiatan, terdapat gambaryang dapat diamati untuk memudahkan siswa dalam memahami pelajaran, terdapat informasi pendukung yang dapat menambah pengetahuan mereka, dan terdapat soal-soal latihan dan soal evaluasi untuk melakukan asesmen secara mandiri.

Menurut Anwar (2010), karakteristik modul pembelajaran yaitu: 1) Self instructional; 2) Self contained; 3) Stand alone; 4) Adaptif; 5) User friendly, 6) Konsistensi, sehingga dengan adanya karakteristik ini dalam modul dapat menuntun dan membantu siswa dalam proses pembelajaran. Sebagai contoh telah terdapat enam kesesuaian modul terhadap karakteristik modul yang terdapat dalam modul pembelajaran matematika berbasis keterampilan literasi pada materi aritmatika sosial, yaitu self instruction, terdapat beberapa kalimat perintah yang mudah untuk dipahami, terdapat soal-soal latihan dan evaluasi yang dapat mengukur kemampuan siswa, serta terdapat rangkuman materi pembelajaran sehingga memudahkan dipelajari secara tuntas. Self contained, yaitu seluruh materi pembelajaran dari unit kompetensi aritmatika sosial terdapat didalam satu modul utuh untuk mencapai kompetensi inti dan kompetensi dasar sesuai dengan kurikulum yang berlaku yaitu kurikulum 2013. Stand alone, modul yang dikembangkan dapat berdiri sendiri ditunjukkan salah satunya terdapat pada lembar kerja dimana siswa dapat melaksanakan seluruh kegiatan pembelajarantanpa menggunakan bahan ajar atau media pembelajaran lain pada modul.Adaptive, artinya bahwa modul memiliki daya adaptasi terhadap perkembangan ilmu dan teknologi. Dan user friendly pada modul aritmatika sosial berbasis keterampilan literasi yang dikembangkan telah dapat bersahabat dengan siswa karena pada modul terdapat instruksi yang membantu dan bersahabat dengan pemakainya. Serta konsistensi, modul yang dikembangkan konsisten dalam penggunaan font, spasi, dan tata letak.

\section{Keefektifan Modul Pembelajaran Matematika}

Kefektifan modul pembelajaran matematika berbasis literasi ini dapat dilihat dari posttest siswa. Posttest yang disusun berbasis keterampilan literasi matematika yaitu terdapat 6 level kemampuan literasi matematika. Hasil posttest literasi menunjukkan bahwa sebanyak 16 dari 21 siswa telah mencapai kemampuan literasi matematika dengan persentase ketuntasan mencapai $76,19 \%$ yaitu pada kategori baik. Berdasarkan uraian pada bab sebelumnya bahwa modul pembelajaran yang dikembangkan memenuhi kriteria keefektifan jika persentase ketuntasan belajar siswa pada postest literasi matematika minimal memenuhi kategori baik, sehingga dapat disimpulkan 
bahwa modul pembelajaran matematika berbasis keterampilan literasi yang dikembangkan efektif digunakan.

Meskipun terdapat 5 orang siswa dari 21 orang siswa pada kelas uji coba belum mencapai kemampuan literasi level 3 atau dengan kata lain bahwa terdapat 5 orang siswa dari 21 orang siswa belum tuntas, akan tetapi secara keseluruhan rata-rata nilai kelas adalah 507 menunjukkan bahwa rata-rata kemampuan literasi matematika siswa berada pada level 3, sehingga modul yang dikembangkan termasuk kategori pada efektif digunakan. Hal ini sesuai dengan keunggulan pembelajaran dengan sistem modul dikemukakan sebagai berikut: meningkatkan motivasi siswa, karena setiap kali mengerjakan tugas pelajaran yang dibatasi dengan jelas dan sesuai dengan kemampuan; setelah dilakukan evaluasi, guru dan siswa mengetahui benar, pada modul yang mana siswa telah berhasil dan pada bagian modul yang mana mereka belum berhasil dan juga dengan penggunaan modul ini siswa mencapai hasil sesuai dengan kemampuannya karena pada hakekatnya para siswa memiliki kemampuan untuk bekerja sendiri dan lebih bertanggung jawab atas tindakan-tindakannya.Hal ini sejalan dengan pendapat Tjipto (1991), mengungkapkan beberapa keuntungan yang diperoleh jika belajar menggunakan modul, antara lain :1. Motivasi siswa dipertinggi karena setiap kali siswa mengerjakan tugas pelajaran dibatasi dengan jelas dan yang sesuai dengan kemampuannya; 2. Sesudah pelajaran selesai guru dan siswa mengetahui benar siswa yang berhasil dengan baik dan mana yang kurang berhasil; 3. Siswa mencapai hasil yang sesuai dengan kemampuannya; 4. Beban belajar terbagi lebih merata sepanjang semester; 5. Pendidikan lebih berdaya guna.

Belajar menggunakan modul sangat banyak manfaatnya, siswa dapat bertanggung jawab terhadap kegiatan belajarnya sendiri, pembelajaran dengan modul sangat menghargai perbedaan individu, sehingga siswa dapat belajar sesuai dengan tingkat kemampuannya, maka pembelajaran semakin efektif dan efisien.

\section{KESIMPULAN DAN SARAN}

\section{A. Kesimpulan}

Berdasarkan hasil penelitian dan pembahasan yang telah diuraikan, dapat disimpulkan dapat disimpulkan beberapa hal, yaitu:

1. Kevalidan modul pembelajaran matematika berbasis keterampilan literasi menunjukkan kriteria sangat valid dengan nilai validitas 3,73, dengan begitu modul pembelajaran matematikaberbasis keterampilan literasi ini pada materi aritmatika sosial memenuhi kriteria kevalidan.

2. Kepraktisan modul pembelajaran menunjukkan kriteria praktis, dengan persentase keterlaksanaan sebesar $94 \%$ berdasarkan kriteria keterlaksanaan berada pada kategori sangat baik, rata-rata respon siswa sebesar3,37 yang dikategorikan baik, serta rata-rata respon guru mata pelajaran matematika di SMP Negeri 1 Gantarangkeke sebesar 3,43 yang dikategorikan sangat baik. Sehingga, dengan 
memperhatikan keterlaksanaan pembelajaran dan respon siswa serta respon guru, dapat disimpulkan bahwa modul pembelajaran yang dikembangkan memenuhi kriteria praktis.

3. Keefektifan modul pembelajaran didasarkan pada hasil posttest literasi matematika menunjukkan persentase ketuntasan mencapai 76,19\% yaitu pada kategori baik. Sehingga dapat dikatakan bahwa modul yang dikembangkan memenuhi kriteria efektif.

\section{B. Saran}

Beberapa hal yang dapat dijadikan sebagai saran dari penelitian yang telah dilakukan sebagai berikut.

1. Modul pembelajaran yang dikembangkan hanya berbasis pada keterampilan literasi matematika secara umum. Hal ini dapat dijadikan sebagaiacuan bagi peneliti lain yang ingin mengembangkan bahan ajar dengan berbasis pencapaian keterampilan literasi matematika pada level tertentu.

2. Disarankan kepada peneliti selanjutnya untuk melakukan ujicoba dalam skala luas agar dihasilkan modul pembelajaran yang lebih baik.

3. Disarankan kepada peneliti lain untuk dapat mengambangkan modul pembelajaran matematika berbasis keterampilan literasipada konsep materi yang lain.

\section{DAFTAR PUSTAKA}

Abdullah, M. Y., Bakar, N. R. A., \& Mahbob, M. H. (2012). Student's Participation in Classroom: What Motivates them to Speak up? Procedia-Social and Behavioral Sciences, 51, 516-522.

Benjamin, B., \& Orodho, J. A. (2014). Teaching and learning resource availability and teachers' effective classroom management and content delivery in secondary schools in Huye District, Rwanda. Journal of Education and Practice, 5(9).

Borg, W. R., \& Gall, M. D. (1983). Educational research: An introduction (Fourth). New York: Longman.

Clark, V. L. P., \& Creswell, J. W. (2014). Understanding research: A consumer's guide. Pearson Higher Ed.

De Jong, T., \& van Joolingen, W. R. (2008). Model-facilitated learning. Handbook of Research on Educational Communications and Technology, 457-468.

Dick, W., Carey, L., \& Carey, J. O. (2015a). The systematic design of instruction.

Dick, W., Carey, L., \& Carey, J. O. (2015b). The systematic design of instruction (Eighth). New York: Pearson. 
Flagg, B. N. (2013). Formative evaluation for educational technologies. New York: Routledge.

Gall, M. D., Borg, W. R., \& Gall, J. P. (2007). Educational research: An introduction. New York: Longman Publishing.

Gentry, C. G. (1994). Introduction to instructional development: Process and technique. Wadsworth Publishing Company Belmont, California.

Grabinger, R. S. (1988). The Design, Development, and Evaluation of Instructional Software. Educational Communication and Technology, Vol. 36,(1), 35-38.

Gustafson, K. L., \& Branch, R. M. (2002). Survey of instructional development models. ERIC.

Hannafin, M. J. (1989). Interaction strategies and emerging instructional technologies. Canadian Journal of Educational Communication, 167.

Hannafin, M. J., \& Hooper, S. (1989). An integrated framework for CBI screen design and layout. Computers in Human Behavior, 5(3), 155-165.

Hannafin, M. J., \& Peck, K. L. (1988). The Design. Development, and Evaluation of Instructional Software, McMillan.

Hattie, J., \& Timperley, H. (2007). The power of feedback. Review of Educational Research, 77(1), 81-112.

Martin, F. (2011). Instructional design and the importance of instructional alignment. Community College Journal of Research and Practice, 35(12), 955-972.

McKenney, S., \& Reeves, T. C. (2013). Conducting educational design research. Routledge.

Molenda, M. (2003). In search of the elusive ADDIE model. Performance Improvement, 42(5), 34-37.

Morrison, G. R., Ross, S. M., Kemp, J. E., \& Kalman, H. (2013). Designing effective instruction. John Wiley \& Sons.

Newby, T. J., Stepich, D. A., Russell, J.

D., \& Lehman, J. D. (2006). Educational technology for teaching and learning. Prentice Hall.

Plomp, T., \& Nieveen, N. M. (2010). An introduction to educational design research.

Prawiradilaga, D. (2009). Salma. 2009. Prinsip Desain Pembelajaran Instructional Design Principles. Jakarta: Prenada Media Group bekerjasama dengan UNJ.

Pribadi, B. A. (2011). Model ASSURE untuk Mendesain Pembelajaran Sukses. Jakarta: Dian Rakyat. 
Richey, R. C., \& Klein, J. D. (2014). Design and development research: Methods, strategies, and issues. Routledge.

Roblyer, M D and Doering, Aa. H. (2010). Integrating educational technology into teaching.

Roblyer, M. D., \& Doering, A. H. (2010). Integrating educational technology into teaching.

Rogers, E. M. (2010). Diffusion of innovations. Simon and Schuster.

Rothwell, William, Benscoter, Bud, King, Marsha, and King, S. B. (2016). Caught in the web of quality. International Journal of Educational Development (Fourth, Vol. Fourth). New Jersey: John Wiley \& Sons.

Rothwell, W. J., Benscoter, B., King, M., \& King, S. B. (2016). Mastering the instructional design process: A systematic approach. John Wiley \& Sons.

Schwarz, C. V, \& White, B. Y. (2005). Metamodeling knowledge: Developing students' understanding of scientific modeling. Cognition and Instruction, 23(2), 165-205.

Seels, B. B., \& Richey, R. C. (2012). Instructional technology: The definition and domains of the field. IAP.

Smaldino, S. E., Lowther, D. L., Russell, J. D., \& Mims, C. (2015). Instructional technology and media for learning.

Smith, P. L., \& Ragan, T. J. (2005). Instructional design. Wiley New York.

Snelbecker, G. E. (1974). Learning theory, instructional theory, and psychoeducational design. McGrawHill Companies.

Yaumi, M. (2016a). Prinsip-Prinsip Desain Pembelajaran Disesuaikan dengan Kurikulum 2013 (Edisi Kedua). Jakarta: Kencana.

Yaumi, M. (2016b). Prinsip-Prinsip Desain Pembelajaran Disesuaikan Dengan Pembelajaran Kurikulum 2013. Jakarta: Kencana. 